\section{Silent God in a Wordy World. Silence in Ignatian Spirituality*}

\author{
José García de CAstro Valdés, S.J.*
}

RECIBIDO: 15-09-15. APROBADO: 23-01-16

\begin{abstract}
Aвstract: The Society of Jesus is an apostolic religious order involved in many different activities and missions. Jesuits live far away from monasteries and strict contemplative life. Nevertheless, one of the most well-known peculiarities of the Ignatian Spiritual Exercises is that a complete and absolute silence is required during the time of the retreat. Where and how should we place "silence" in the life of an Ignatian spiritual and mystical experience?

KEY wORDs: Action, Ignatius of Loyola, Ignatian Mysticism, Retreat, Silence, Spiritual Exercises.
\end{abstract}

PARA CITAR ESTE ARTÍCULO:

De Castro Valdés, José García. "Silent God in a Wordy World. Silence in Ignatian Spirituality". Theologica Xaveriana 181 (2016): 177-205. http:// dx.doi.org/10.11144/javeriana.tx66-181.sgwwsis
El Dios silencioso en un mundo locuaz. El silencio en la espiritualidad ignaciana

Resumen: La Compañía de Jesús es una orden religiosa de carácter apostólico que está inmersa en diferentes actividades y misiones. Los jesuitas viven lejos de los monasterios y de la estricta vida contemplativa. No obstante, una de las peculiaridades mejor conocidas de los Ejercicios Espirituales ignacianos es el silencio completo y absoluto que es requerido durante el tiempo del retiro. ¿Dónde y cómo deberíamos ubicar el "silencio" en la vida de la experiencia mística y espiritual ignaciana?

Palabras clave: Acción, Ignacio de Loyola, misticismo ignaciano, retiro, silencio, Ejercicios Espirituales.

O Deus silencioso em um mundo loquaz. O silêncio na espiritualidade ignaciana

Resumo: A Companhia de Jesus é uma ordem religiosa de caráter apostólico que está imersa em diferentes atividades e missóes. Os jesuítas vivem longe dos monastérios e da rigorosa vida contemplativa. Náo obstante, um dos melhores recursos conhecidos dos Exercícios Espirituais Ignacianos é o silêncio completo e absoluto que é necessário durante o tempo do retiro. Onde e como deveríamos localizar o "silêncio" na vida da experiência mística e espiritual ignaciana?

Palavra Chave: Ação, Ignacio de Loyola, misticismo ignaciano, retiro, silêncio, Exercícios Espirituais.

*Article based on a lecture given in the International Conference "Ignatian Silence: Heart of Mission", (Saint Louis, MO, July 16-19, 2015).

** Doctorate on Hispanic Philology, Salamanca University. Teacher and Director of the Master Ignatiana on Ignatian History, Spirituality and Theology, at Comillas University. E-mail: Joségc@comillas.edu 
To Javier Osuna, S.J.:

In memoriam

\section{Silence as Experience of the Origins}

In Greek mythology, Harpocrates is the god of Silence. He is often depicted as a naked boy, with the index finger of his right hand pressed against his lips ${ }^{1}$, wearing a royal crown and a pony-tail on the right-hand side of his head, a characteristic of Egyptian princes. We find Silence in all religious traditions, as one of the most important contexts in which religious experience happens. Harpocrates reminds us how old is the relationship between Silence and Religion. The mystery of God has always been related to the mystery of Silence ${ }^{2}$.

Before the sound of the wind and breeze, before the ripple of the rivers, before the continuous echoes of the sea, before everything, maybe nothing was heard. Indeed, there is a cosmic dimension in the silence we experience in a quiet night, open to the firmament, full of stars, in an atmosphere of solitude and retreat.

More so, this is like a proto-experience, an experience of our origins. The silence of the cosmos, of the world, is given to me as a religious act of adoration. Being embraced by Silence, "when a peaceful silence lay over all" (Ws 18,14), makes me wonder if where I come from (my origins, my source) is an experience of Silence.

In the beginning was the Word (John 1,1). A Word that was spoken from somewhere. Or was Divinity Absolute Silence before speaking? What did God hear from himself before pouring himself into the Word? Silence's departure from mystery was called Son; Silence was the eternal room of Divinity. "God speaks ever in eternal silence"3.

Ignatius wrote: "And the greatest consolation he used to receive was to look at the sky and the stars, which he did often and for a long time, because with this he used to feel in himself a great impetus towards serving Our Lord" $[A u 11]^{4}$.

\footnotetext{
1 "Quique premit vocem digitoque silentia suadet" (Ovidio, Metamorphosis, lib. 9).

${ }^{2}$ Very complete panoramic view in Kaufmann, "Silencio", 1655-1667.

${ }^{3}$ Saint John of the Cross, "Points of Love", III, 21.

4 "Y la mayor consolación que recibía era mirar el cielo y las estrellas, lo cual hacía muchas veces y por mucho espacio, porque con aquello sentí en sí un muy grande esfuerzo para servir a nuestro Señor". (Saint Ignatius of Loyola, Autobiography 11 [from now on, Au]. Quotations are taken from Munitiz and Endean (eds.), Reminiscences or Autobiography. Personal Writings of Saint Ignatius of Loyola. Spanish texts, on footnote, are taken from San Ignacio de Loyola, Obras completas. Numbers between brackets [ ] refer to international number of paragraphs in the editions of Ignatian sourcers.
} 


\section{Ignatius' first contacts with Silence}

\section{Loyola: Muteness and Ascetic Silence}

Deep silence was not made in Íñigo de Loyola’s life until the age of twenty-six. Until then, it had been a life of continuous "noise": the noises of the vainglory, conceit, superficiality and, above all, the noise of distraction 5 .

Until he was forced to meet silence, Ignatius lived distracted from himself. Indeed, we do know that he was a man of words, and that arguing and persuading, which he had surely practiced while studying Grammar and Rhetoric in Arévalo, were some of his strengths: "...he gave so many arguments to the commandant that even then he persuaded him to make a defence [of the fortress], though against the opinion of all the knights" $[A u 1]^{6}$. Only the thunderous noise of the cannon ball which hit his leg was able to provoke his fall toward Silence, who was patiently waiting for distracted Íñigo.

Noise seeks for, and provokes, more noise. And Ínigo's noisy heart needed more noise in order to feed his self-complacency and inner disquiet. The silence of Urola Valley in Loyola and the strange solitude of his third-floor room appeared to be too foreign to what his inner life was used to.

In this absence of words, Ínigo was not silent, but mute. Circumstances forced him to keep silence. This inability to communicate became unbearable. He asked for distractions, for his favorite entertainment, books of chivalry, "books of noise".

At Loyola, however, only "books of Silence" were at hand. His sister in law, Magdalena de Araoz", became for him the "angel of Silence". Vita Christi (The Life of Christ) became for Ínigo the "secret ladder", in terms of St. John of the Cross. The reading of each mystery of Vita Christi would decrease the volume of wordy voices in his heart.

Silence gradually filled it all, and started its own process and dynamic beyond Ignatius's own consciousness. A part of him was being opened up to God's encounter

${ }^{5}$ Fr. Adolfo Nicolás, Fr. General of the Society of Jesus, also talked about "distractions" as one of the threats for the Mission of the Society of Jesus. Maybe his interest on silence (Nicolás, "De statu Societatis Iesu") is pointing to offer an answer to so many distractions around the apostolic life.

6 “...él dio tantas razones al alcaide, que todavía lo persuadió a defenderse, aunque contra el parecer de todos los caballeros" (Saint Ignatius of Loyola, Autobiography, 1). Emphasis is mine.

${ }^{7}$ Magdalena de Araoz was the wife of his brother Martín García Oñaz. They married in 1498 when Ignatius was eight years old. Maybe when María Sanz de Licona, mother of Ignatius, passed away, Magdalena behaved as a "second mother" for Ignatius. 
and, silently, the good spirit found there the necessary empathy to begin his work of transformation: "they [spirits] come in quietly, as someone comes into one's own home opening the door" $[E x 335.6]^{8}$.

In Vita Christi we read: "Seek solitude and escape the hustle and bustle if you want to unite yourself with God [...]. Flee from too much speech and keep quiet" .

The noise of the previous twenty-six years began to contrast with a new and unknown inner voice -as a gentle and soft breeze- that started to pronounce new and strange words inside him. Ignatius did not like what this silent light of the Spirit was discovering about himself. He passed moral judgment on his past life and "began to think about how much need he had to do penance for it" [Au 9].

As we read in Autobiography: "... it occurred to him to go into the Charterhouse in Seville. He also instructed a house-servant, who was going to Burgos, to find out about the Rule of the Charterhouse, and the information he got about it seemed to him good". ${ }^{10}$ It was the penitent search for an ascetic silence understood as a chivalric renunciation of his disordered past, so as to "always live in penance" [Au 12].

Silence, however, also allowed him to hear other inner voices, not only that of his past life's disorder, but also the voice of the knowledge of Jesus, which showed its affective dimension in the movements of his heart. Consolation started to emerge slowly in his soul as a daughter of divine Silence ${ }^{11}$.

We do not know the exact date in September or October 1521 when Ignatius was, we could say, born for Silence: "when his eyes were open a bit" $[A u$ 8]. Silence emerged after a process of progressive descent toward consolation: quieting the noise of physical pain, silencing the noises of memory and fantasy, receiving the new voice of good spirit, making consolation conscious. In this time of retreat in Loyola, Ignatius began feeling and tasting the value of silence. The tower-house of the family started to transform into the first "Jesuit" retreat house.

8 “...entra con silencio, como en propia casa a puerta abierta" (Ex 335. 6) (Ex: Spiritual Exercices). See: Missoffe, "Comme la goutte d'eau", 221-228.

9 "Busca la soledad, apártate del alboroto, si quieres unirte con Dios y verle con la pureza de corazón. Huye del mucho hablar y guarda silencio" (Ludolfo de Saxonia, La vida de Cristo, I, 217).

10 “...ofrecíasele meterse en la cartuja de Sevilla, sin decir quién era para que en menos le tuviesen [...] todavía un criado de casa, que iba a Burgos, mando que se informase de la regla de la Cartuja, y la información que de ella tuvo, le pareció bien" (Saint Ignatius of Loyola, Autobiography, 12).

${ }^{11}$ Le Bourgeois, "La rumeur de Dieu dans notre monde", 200-208. 


\section{Ignatius: building a silent heart}

But not all had been completed at Loyola. Other kind of new noises came up in Ignatius' life: devote and pious noise, maybe, but noise all the same: penance, fasting, using disciplines... cries from a wounded memory, temptations, scruples... So many voices inside shouting in the middle of a new battle, deeper and "bigger" than the recent one against the French troops in Pamplona. The battle against himself in Manresa (1522-1523).

In the midst of all these voices, others also made themselves heard. And again another book of Silence arises. Ignatius read the "little Gerson", the Imitation of Christ (Kempis) in Manresa, and was so impressed by it that he claimed he would never read any other devotional book ${ }^{12}$. Chapter 20 of Part I is devoted to "the love of solitude and silence":

....in silence and peace a devout soul makes progress and learns the secrets of the Scriptures. Only in silence and peace does a devout soul find floods of tears, in which it may wash and cleanse itself each night. The further the soul is from the noise of the world, the closer it may be to its Creator, for God, with his holy angels, will draw close to a person who seeks solitude and silence. ${ }^{13}$

Later on, Kempis states:

As much as you can, avoid being caught up in day-to-day business, for spending too much energy on it gets in the way of our spiritual journey. [...]. I often wish that I had kept silent and had not been so quick to venture out into the world. I wonder why are we so eager to chatter and gossip with each other, since we seldom return to the quiet of our own hearts without a damaged conscience? ${ }^{14}$

And he finally concludes: "Oh, how good and how peaceful it is to keep silent about others and not to believe gossip or spread it around". ${ }^{15}$

\footnotetext{
${ }^{12} \mathrm{He}$ assimilated it to such an extent that he himself resembled "a living lesson from Gerson" [98] (Gonçalves da Câmara, Remembering Inigo. Glimpses of the Life of Saint Ignatius of Loyola. The Memoriale of Luis Gonçalves da Câmara, 58; “... a conversation with the Father seems like a reading of Jean Gerson put into practice” [226] 131; “...y así, estar conversando con el Padre [Ignacio], no parece sino estar leyendo a Juan Gerson” (Gonçalves da Câmara, Memorial, 92-93) [97-98]. At the times of Ignatius, the book Imitation of Christ was attributed to John Gerson (1363-1429), Chancellor of Sorbone University in París, and well known theologían and spiritual man. See: García Mateo, "Imitación de Cristo", 994-1001.

${ }^{13}$ Thomas a Kempis, Imitation of Christ, I, Ch. 20 [6], 50.

${ }^{14}$ Ibid., I, Ch. 10 [1], 38.

${ }^{15}$ Ibid., III, Ch. 45 [6], 137.
} 
But before leaving Manresa, we must have a look to another text, maybe one of the books which influenced, in a deeper way, on the first steps of Ignatius towards his friendship with God: The Exercitatorio de la vida espiritual ${ }^{16}$ of García Jiménez de Cisneros ${ }^{17}$, printed in Monserrat in 1510. Ignatius could have known this text through the Compendio breve, a shorter version of the Exercitatorio prepared by an anonymous monk of Montserrat ${ }^{18}$.

Cisneros insists on retreat, loneliness and silence as elemental conditions for the religious experience of the monks: "the second [condition], inner silence is required in such a way that the noise of all exterior things became quiet"; and the title of Chapter 39 is: "On two ways of Silence and Loneliness", where we read: "...but it is true that the main secret and silence must be more inside the soul than outside" 1 .

Cisneros considers silence as a higher step on the road to the mountain of contemplation: "it is necessary a strong perseverance in the mentioned levels: humble patience, secret place and silence" ${ }^{20}$; and recommends silence while monks are busy working in their ordinary activities: "keeping mainly the silence, because according to the prophet in the silence lies our strength (Is 30, 15) ${ }^{21}$ ".

Even though in Manresa, Ignatius became aware of the apostolic character of his vocation, and the increasing importance of "helping souls" in his life, mainly through conversations, through words, it is clear that Ignatius gradually increased his sensitivity toward silence.

He learned to remain quiet, using silence as a rhetoric strategy: facing the Inquisition authorities in Salamanca, he answered, "Father, I won't say more than what I've

${ }^{16}$ Critical edition: Jiménez de Cisneros, Obras completas II. Texto, 89-455. See also: Ibid., Vol. I. Introducción e indices. English translation of the Exercitatorio: García Cisneros, A Book of Spiritual Exercises and the Directory for the Canonical Hours.

${ }^{17}$ García Jiménez de Cisneros (1455-56?-1510) was elected prior of the benedictine monastery of Monserrat in 1493 and reelected during seventeen years until he died in 1510 (since 1499 he was Abbot of the community). Through him and his works the Devotio moderna was introduced in Spain and was one of the spiritualities that had a deeper influence on Ignatius of Loyola.

${ }^{18}$ See: Melloni (ed.), Compendio breve de los Ejercicios Espirituales. Compuesto por un monje de Montserrat entre 1510-1555, and Idem, "Las influencias cisnerianas de los Ejercicios", 353-378.

19 "De dos maneras de silencio y soledad" ("De doubus modis silentii et solitudinis"), Jiménez de Cisneros, Obras completas II, 296-299; 296.

20 "...es necesaria la fuerte perseverancia con los grados sobredichos, conviene a saber, humilde paciencia, lugar secreto y silencio" (Jiménez de Cisneros, Obras completas, Ch. 63; 420).

${ }^{21}$ And follows: "And if silence must be kept always and in everywhere [...] it is in the work of our hands, according to the apostle: "We pray to the Lord you could eat you bread in silence"' $(2$ Ts 3,12$)$. 
already said, unless it be in front of my superiors who can require it of me" [Au 66]. The Dominican friars "couldn't get another word out of the pilgrim apart from this" [Au 66]. Ignacio was following the teaching of Evagrius Ponticus in the 4th Century:

Give no reply at all to those who make threats, that by your silence you may stifle the fiery lips [...]. For if you remain silent you will not be eaten up by the offence, but the other person is all the more bitten by your silence, when you bear patiently with the insult of the arrogant man. ${ }^{22}$

According to the few accounts available to us, Ignatius highly valued silence and wished it present in religious communities as a natural way of living. On October 18, 1555, Fr. Câmara recorded Ignatius' irritation at the lack of silence in the house of Rome, in his Memorial, describing the situation as "contrary to moderation and edification to talk in a loud voice in this house". As a punishment, Ignatius barred Fr. Olave from entering the house during one month, and appointed two syndics [sindicos] to prevent speaking in the corridors "except in a very low voice"23.

Moreover, Ignatius came into conflicts due to lack of silence, often in his house in Rome that was "old and crumbling" ${ }^{24}$, and which often disturbed his prayer, as reflected some times in the Spiritual Diary (15 May 1544): "No tears; some loquela; I was disturbed by someone whistling, but was not so greatly disquieted" [Sp D 227].

\section{First companions, friends of Silence}

Inspired by the personal experience of Ignatius, Silence was around the first religious experience of the companions. The accounts of the first Jesuits suggest that during their studies in Paris they were in close contact with the Carthusian monastery, which they would visit regularly on Sundays and holidays, "in order to confess and receive communion frequently, together with other pious student friends", as Nicolás de Bobadilla says in his Autobiography ${ }^{25}$.

\footnotetext{
${ }^{22}$ Evagrius Ponticus, “To Eulogios”, 32 [4].

${ }^{23}$ Gonçalves da Câmara, Remembering Inigo [413] 221. "I must remember how much importance he gave to the fault and appointed two syndics to impose penances on everyone, including the Vicars. No one shoud stop to talk in the corridor, excpet in a vey low voice"; "[cosa] tan vergonzosa, tan desmesurada y tan desedificativa, que se hable alto en esta casa” (Idem, Memorial [413] 249).

24 "Vivíamos con grande pobreza y estrechura en una casa alquilada, vieja y caediza" (Ribadeneira, Vida de Ignacio de Loyola, III, 1). See also: L. D., Fontes narrativi III, mon. 7, 175-182.

${ }^{25}$ Bobadilla, Monumenta Bobadillae, 615.
} 
Fr. Jerome Nadal, in his Chronicon (1535), mentions "holy meetings at the charterhouse on Sundays and holidays" ${ }^{26}$. Moreover, it should be noted that Peter Faber's hometown was close to the Reposoir monastery (Savoy), where two of his uncles (George and Albert) had served as priors and this first companion of Ignatius developed a deep and friendly relationship with the Carthusians ${ }^{27}$.

Maybe because the first Jesuits had gone through the process of "election" in their personal experience in the Spiritual Exercises in a very strict silence ${ }^{28}$, they decided to use a similar silent method in their deliberations around the Foundation of the Society of Jesus.

In Lent, 1539, the companions met in Rome and began the process of discernment on whether they should go their own way or remain together as some type of union or congregation. Silence played a central role in the method they followed during several weeks. They spent the day praying individually, without communicating with the others, and at night they would share with the group whatever each of them had felt and received from the Spirit ${ }^{29}$. Silence guaranteed that the dialogue would truly reflect the experiences of prayer $^{30}$.

Nevertheless, in spite of this friendly relationship with the charterhouse, Jesuits soon distanced themselves from this way of understanding silence. "We are not monks", Nadal proclaimed continuously ${ }^{31}$. "If flight from dangers of the world was the reason

\footnotetext{
${ }^{26}$ Monumenta Natalis, I, 2.

${ }^{27}$ See the letter to Fr. Claudio Perisin written from Maguncia (May 28, 1543) in Monumenta Fabri 201202. The Jesuit Lamberto de Leodio was buried in the Charter House of Colonia (Monumenta Fabri 303.464). See: Falkner, "Cartuja”, I, 306-311.
}

${ }^{28}$ There is no much information about the experience of spiritual exercises of the first companions. Fr. Gonçalves da Câmara offers few lines in his Memorial about the Exercises Peter Faber did in Faubourg St. Jacques "at a time when people were crossing the Seine in carts because it was frozen" [305].

29 “....secunda animi preparatio est, quod nullus ex sociis apud alterum socium hac de re verba faceret, vel quereret ab eo rationes, ut nulla alterius persuasione alius traheretur, et flecteretur magis ad obediendum quam ad non obediendum, vel contra; sed quos unusquisque id solum quaereret, quod ex oratione et meditatione, tanquam expedientius, hausisset" (Monumenta constitutionum I, [Roma 1913], 5). See: Conwell, “Deliberaciónes 1539”, I, 549-553; Idem, Impelling Spirit. Revisiting a Founding Experience 1539; Osuna, Amigos en el Señor. Unidos para la dispersión, 142-156.

${ }^{30}$ This way of proceeding was introduced in the VIII Part of the Constitutions; its sixth chapter is about: "The manner of reaching a decision in the election of a general", and in paragraph [702] we read: "In the locked room all will keep silence until the General is elected, in such a manner that one does not speak with another about anything pertaining to the election" (Society of Jesus, The Constitutions of the Society of Jesus, 302).

31 "Y assi nosotros no somos monjes, ni tenemos las particularidades que sanctamente tienen las religiones monásticas", in "Exhortationes complutenses" No. 10 (1561), Monumenta natalis V, 413-414. 
so many joined the Society, he needed to disabuse them from the mistaken notions about the character of the Society that this motivation seemed to imply" 32 .

Then, we must recognize that during the first years of the young Society of Jesus there was not a very clear relationship with silence, and Jesuits who tried to explore deeply a prayer of Silence remained under the eye of the ecclesiastical authorities.

One of the most interesting cases is Father Baltasar Álvarez (1533-1580) ${ }^{33}$. Already novice Master in Medina del Campo (Valladolid, Spain), he experienced from 1566 on a prayer of quietness and a passive contemplation that lead him to understand his experience of prayer as profound silence: "My prayer is putting myself in his presence, being quiet before him, presence given interiorly and corporeally to be quiet in his presence is a great treasure" 34 .

This way of praying was not original, and Fr. Álvarez himself provides a list of references to back him up: Dionysius the Areopagite (De Mystica theologia), Saint Augustine (Epistle 17), Saint Gregory (On the Apocalypse), Saint Bernard (Cantica, Sermon 54), Saint Thomas (Summa II.2, q 182 art. 2), Saint Albert the Great (De adherendo Deo, c. 10) $)^{35}$.

The authorities of the Society feared that Álvarez's method would divert the novices and other Jesuits from the active and apostolic Ignatian charisma. They also feared that the Inquisition might associate such methods of prayer with those of the Spanish alumbrados, a mystical sect that had been condemned several times including in 1575, in Álvarez's time. This pious Jesuit had been confessor of Sainte Theresa of Ávila for six years.

They met for the first time in 1559, only few months after his ordination in 1558, and the mystic Carmelite had a deep influence in the spiritual life of the Castilian Jesuit ${ }^{36}$; we must not forget that in 1574 and 1575 Sainte Theresa was accused of alumbradism, and not all Jesuits at that time were supporting her ${ }^{37}$.

32 “Exhortationes complutenses” No. 10, 413 y “Dialogus II (1562-1565)”, in Monumenta Natalis V: "Ignatius nullum Ordinem monachorum instituerit, sed clericorum, etenim est Societas" (Ibid., 608). See also: O’Malley, The First Jesuits, 67-68 (Spanish trans.: Los primeros jesuitas, 92-93).

${ }^{33}$ Ruiz Jurado, "Álvarez, Baltasar", 91-93 (DHC). See: Endean, “The Strange Style of Prayer”, 351-397; 360-367; Iparraguirre, "La oración en la Compañía naciente", 455-487.

${ }^{34}$ Álvarez, "Escritos acerca de su modo de oración”, 221.

${ }^{35}$ Ibid., 222-223. In 1573, Álvarez wrote a letter to his Fr. Provincial explaining his way of prayer. (See: De la Puente, Vida del padre Baltasar Álvarez, 113-120).

${ }^{36}$ There are many references to Baltasar Álvarez in the Life and letters of Sainte Theresa: "Era un padre bien santo [...], era muy discreto y de gran humildad" (Santa Teresa de Jesús, "Vida”, 28, 14); "Es de los amigos mayores que tengo [...], es un santo" (Santa Teresa de Jesús, "Carta a Isabel Osorio, 8 de abril de 1580", 1003). See: Álvarez, “Álvarez, Baltasar, S.J. (1533-1580)”, 676-678.

${ }^{37}$ De Dalmases, “Teresa de Jesús”, 3777-3778. Similar situation with another Jesuit: López Azpitarte, 
Moreover, there had been cases of young Jesuits in the Spanish province of Aragon who had joined the Carthusian order. For all these reasons, Fr. Mercuriano, after hearing all the testimonies of the superiors and having read all the reports, asked Álvarez to teach the novices only the methods of prayer suggested by the Exercises. Álvarez faithfully complied with Mercuriano's request ${ }^{38}$.

\section{The inner structure of Silence}

Silence is a complex reality in religious experience. Under the word silence there are different proposals that, in my opinion, have an organic structure. If we use a geometrical metaphor we could say that silence can be experienced in different levels of depth. Then, the more we are descending in our relationship with God the more silence opens to new spiritual meanings and theological interpretations. From the absence of external noise till the proper linguistic code of the Holy Spirit; let's try to "pilgrim down" in search of the value of mystic Silence in the apostolic life of the Jesuit.

\section{Silence about Silence}

It is interesting to note that, despite the methodological relevance given to silence in the Spiritual exercises, it is not an important topic in the Ignatian text. The word silence appears only once, when discussing the actions of the good spirit in the soul, in the seventh rule of the second week: "the good spirit comes into the soul in silence, as in his own house when the door is open" [Ex 335.6]. What should we make of this? Was silence not one of Ignatius concerns?

The word silencio was quite common in the times of Ignatius. It comes from the Latin silentum, which in turn comes from silere, "to be quiet". In Spanish, the word is documented since the origins of the language, in the writings of the Castilian clergyman Gonzalo de Berceo, between 1220 and $1250^{39}$.

\footnotetext{
"Influencia de Santa Teresa en las obras de D. Álvarez de Paz”, 25-43.

${ }^{38}$ We can also see the case of P. Antonio Cordeses, briefly, in Endean, "The Strange Style of Prayer", 352-360. For these Spanish authors and "conflicts": Zas Friz, "La tradición mística ignaciana. I. Autores españoles de los siglos XVI y XVII”, 391-406.

${ }^{39}$ See: Corominas and Pascual, Diccionario critico etimológico castellano hispánico, V, 246. Sebastián de Covarrubias, in his Tesoro de la lengua castellana o española, one of the first "dictionaries" of the Spanish language, hardly pays any attention to it: "Vale idem quod taciturnitas" (938).
} 
If words are the gateway to experience, it must be said that silence is not a major topic of interest in important documents of the Ignatian heritage. His Autobiography mentions silence only twice $[A u 44 \text { y } 98]^{40}$, and the thorough indexes of the Exercises, as published in the lengthy volume No. 100 of Monumenta historica Societatis Iesu, only includes one entry, which refers to the water drop entering the sponge [Ex. 335. 6] $]^{41}$. In the Spiritual Diary, an impressive mystical text, there are no explicit references to silence, and only three are found in the Constitutions [Co 249.250 y 702 $]^{42}$.

Father José de Guibert did not show concern for this topic and neither does it appear in the index of his marvelous book ${ }^{43}$. Moreover, when we look at the indexes of the latest General Congregations, 31 to 35, we only find two entries: In CG 31 [decree 19.8f] "conditions of silence and retreat" and in CG 33 "times of solitude and silence" [decree 1.75$]^{44}$.

\section{A place for Silence}

But lets go back to Ignatius. Loyola seems to include the experience and value of silence in the terms apartarse and apartamiento (to be retired) ${ }^{45}$ : "the more one disengages oneself from all friends and acquaintances, the more profit will there be" $\left[\begin{array}{ll}E & 20\end{array}\right]^{46}$. Even so, there isn't a major emphasis on these words either: of the six times the verb apartarse is used, four of them can be found in annotation $20^{47}$. From the use of the

${ }^{40}$ Two miles before reaching Jerusalem, from the place the Holy City could be seen: “...it would be good were all to prepare their minds and hearts and to travel in silence" [Au 44]; "The legate ordered a silence...." [Au 98].

${ }^{41}$ Sancti Ignatii de Loyola, Exercitia spiritualia, 783.

42 [249]: "Ordinarily it is not good for the novices to hold their conversations with one another, but rather to keep silence among themselves"; [250]: "to preserve themselves [the senses] in peace and true humility of their souls, and to give an indication of it by silence"; for [702] see note 35.

${ }^{43}$ De Guibert, The Jesuits. Their Spiritual Doctrine and Practice.

${ }^{44}$ Finally, there are no references in the texts of Father Arrupe and only one in Father Kolvenbach's lecture entitled "Sobre lingüística y teología", where he shows the value of silence in a marvelous dialectic relationship with the Word to build up the theological thought. See: Arrupe, La identidad del jesuita en nuestros tiempos; Kolvenbach, Selección de escritos (1983-1990), I, 587-598.

${ }^{45}$ Apartamiento: is the word used by García Jiménez de Cisneros who offers a definition: "Apartamiento: Those who often want meditate must move away from all concupiscence and appetite of honor, delights and wealth, and from all activity in exterior matters. Because the "fantasmas" of all these things are cause of distractions in the mind" (Jiménez de Cisneros, "Exercitatorio de la vida spiritual", Vol. II, Ch. 69, 444). 46 “...aislarse o separarse de lo conocido y de los conocidos para mas aprovecharse” [Ex 20].

${ }^{47}$ The fifth one is in the first week, "put away from myself worldly and aimless things" $[E x 63,4]$ and, finally, the sixth one refers to how the body of Christ became "separated from the soul" [Ex 208]. 
terms apartarlapartamiento we have deduced the need to carry out the 30-days retreat in silence, even if this is not explicitly stated in Ignacio de Loyola's little book ${ }^{48}$. In fact, the second meaning of the word "silencio" offered by the Diccionario de autoridades connects silence and places: "Metaphoricaly [silence] is the quietness or peace of the places where there is no noise" 49 .

Then, how is it that Jesuits and Spiritual Directors are usually so worried about silence during the Ignatian retreats? Those who really cared about Silence were the Jesuits authors of what we called the Directories ${ }^{50}$. The so-called Directorio autógrafo (the one we preserve from Saint Ignatius) insists that the setting of exercises must be such that the retretant be seen as little as possible, and chatter should not be possible ${ }^{51}$.

Even if silence as such is mentioned very few times, Ignatius does insist on how the venue of the exercises must be retired, thus implying an experience of silence, as may other directories show: a place that is "secluded" 52 " isolated" 53 , "secluded and private"54, "secluded"55, "secluded room" "56; "secluded"57, "a suitable place where he will not be seen or interrupted by family and friends" ${ }^{8}$. In Polanco's words, a "suitable place where the retretant can enjoy solitude" 59 .

\footnotetext{
48 See: González Magaña, “Apartamiento” I, 179-181.

${ }^{49}$ Real Academia Española, Diccionario de autoridades (1737), III; s.v. "Silencio".

${ }^{50}$ A Directory of the Spiritual Exercises is a handbook containing very practical instructions about how to give the Spiritual Exercises to different people. We preserve around 40 directories. Among all of them, the most important one is the Official Directory approved by Fr. Claudio Acquaviva, 5th General Superior of the Society of Jesus in 1599. According to the first testimonies, the second one which had a deep influence in the Official Directory was the one written by Fr. Juan Alfonso de Polanco (1573-1575). Directories are published in its critical edition in Monumenta historica, Vol. 76: Exercitia spiritualia Sancti Ignatii de Loyola et eorum Directoria, Nova editio (I. Iparraguirrre, ed.; Roma 1955). Apart from this, I am using two editions: Los directorios de Ejercicios (1540-1599); and On Giving the Spiritual Exercises. The Early Jesuit Manuscript Directories and the Official Directory of 1599. I will abbreviate: D, followed by number of Directory and number of paragraph.

51 “...quanto menos pueda ser visto, ni platicar con ninguno” (Exercitia spiritualia, 70).

52 “...recogido": D4 [4].

53 “...apartado": D7 [19]; D29 [38]; D32 [13].

54 “...alejado": D18 [94], latin word: “...separatus et secretus”.

55 “...secreto": D12 [15]; D17 [40]; D18 [94].

56 “...separado": D12 [19]; D18 [94]; D22, 23 [9]; D31 [50].

57 “...remoto": D22, 23 [9]: “...in locum secretiorem domus suae”; D33. 34.43 [36]: “...remotus ad hominum concursu".

58 “...solitario": D20 [26]: “...nec a familiaribus, nec ab aliis”.

59 “...lugar idóneo, donde el que se ejercita pueda disfrutar de soledad”: D20 [8].
} 


\section{Silence as home and path to mystery}

In his Autograph Directory, Ignacio stated that "where he will be least able to be seen or talk with anyone" ${ }^{60}$. In his Directory (1525-1608), Fr. Hoffeo talks about "strict and uninterrupted silence". If retretants need to ask for anything, they should do it in written form (D17 [58]). Hence the brief instruction, following Mercurian, "It is preferable for the exercitant to talk with no one at all except the director" ${ }^{\prime \prime}$.

The Official Directory also provides some guidelines regarding any helper in charge of supporting the retretant in material aspects.

In this place, besides a director, the retretant should also have someone to wait on him and bring him his meals. This should be a trustworthy person, discreet, silent, and one who will give edification by the example of his modesty, humility, and devotion. He should talk only about things connected with the retreatant's food, room, or service- and that in the fewest possible words, always referring everything to the director. ${ }^{62}$

St. John of the Cross issues the final warning: "Conquering the tongue is better than fasting on bread and water"63.

Silence is the house of Ignatian religious experience, a home for the religious word: preambles, points, colloquies and exams. All is inhabited by silence and all inhabits silence. In Exercises, it is only the right word that must be pronounced at every moment: the only one that will help descend toward silence through silence. Others do not belong, they can be consider as empty words and might even become an obstacle for the experience. The first thing Ignacio does after offering a definition of the Exercises $[E x 1]$ is recommending a tight control over words: "simply running over the salient points with brief or summary explanations" $[E x 2]^{64}$.

The human word the Spiritual Director offers to the retreatant is a mystagogic word, a secondary word, aimed at facilitating hearing the divine Word, which is the

\footnotetext{
60 “...cuanto menos pueda ser visto, ni platicar con ninguno": D1 [2].

61 “...convendría que no hablase absolutamente con nadie, salvo con el que da los ejercicios": D18 [94].

62 "En este lugar, además del Instructor, debe haber uno que le sirva y que le lleve lo necesario para la comida. Conviene que este sea fiel, discreto, callado y tal que edifique con su modestia y ejemplo de humildad y devoción. No le ha de hablar sino de lo que se refiere a la comida o habitación y servicio suyo, y eso con poquísimas palabras, remitiéndose en todo siempre al Instructor" (D33, 34, 43, 38). Something similar in the Directorio of Father P. Mirón (D22.23, 22).

63 “...es mejor vencerse en la lengua, que ayunar a pan y agua" (San Juan de la Cruz, "Dichos de luz y amor”, No. 181, 105).

${ }^{64}$ “....discurriendo solamente por los puntos, con breve o sumaria declaración” [Ex 2].
} 
one that dwells in silence. Upon hearing this human word, the action of the Spirit leads the retretant to silence, where he/she is ready to "hear" the words of mystery: "to hear with the sense of hearing what they say or could say" ${ }^{65}$, for example, in the Nativity scene [Ex 123] or in the Lord's Last Supper [Ex 194].

But words in mouth are daughters of words in thoughts; then, silence becomes the necessary environment of the inner dynamics of the self. Every "operation" that takes place in the soul has to be listened in her complete process, from the beginning till the very end ${ }^{66}$. Silence is required to identify the true "agent" of every "thought". Taking distance from other spiritual schools or methods that tried to refuse all thoughts in the deep spiritual experience ${ }^{67}$, Ignatius discovered that God can also talk and reveal his will through the inner discourse of our thoughts. It is what Autobiography first discernment in Loyola is about ${ }^{68}$ and what "Rules for Second Week Discernment" try to focus: on thoughts ${ }^{69}$.

The Official Directory insists that the retretant's "endeavor should be to shut out every other consideration, no matter what it may be, just as if he had no other business in the world"70. Silence must favor a progressive focusing of thoughts. In this way, for instance, Polanco recommends that "the retreatant should be told that even if he brought books with him, during this First Week he should not read them but should instead concentrate his thoughts and affections on cleansing his conscience

65 “...advertir y contemplar lo que hablan" [Ex 123].

66 "....if the beginning, middle and end are entirely good and tend towards what is wholly right..." $[E x$ 333].

${ }^{67}$ For Evagrius, thoughts are mainly the beginning of the temptations, "tools" in hands of different demons. See, for example "On the eight thoughts" in Praktikos, cit. [6-14] 97-98; Monks [37] 124, [58] 126... (see Index in 368). Then, to grow in spiritual life implies to empty all kind of thoughts from the mind.

${ }^{68}$ Thoughts and thinking: "...he would stop to think" [Au G]; "causing other thoughts", "he would stop to think", "succession of different kind of thoughts", "always dwelling on the thought" [Au 7]; "when he was thinking about that", "such thoughts", "from some thoughts he would be left sad, and from others happy” $[A u$ 8].

${ }^{69}$ "...to bring good and holy thoughts" [Ex 332]; "in the course of the thoughts" [Ex333]; "at the course of the good thoughts" [Ex334].

70 "...todo pensamiento de cualquier otra cosa, como si no tuviera ningún otro negocio en este mundo" (D33. 34. 43 [21], Los directorios, 325); English translation prefers "consideration" instead of "thought" (On giving, 295). 
through the exercises for arousing contrition"71. For Polanco, solitude and silence are the two main means to cooperate with divine grace and prepare us to receive great gifts ${ }^{72}$.

\section{Theological value of Silence}

"Loneliness and Silence do not make a Hesychast". Theologically, we are not in Silence only because we have been able to control our tongue and our thoughts. Once we are there, Silence opens up its theological horizon. Silence starts to show, not its negative face as absence of sounds, but its deictic face. Once silence has been assumed and integrated, "once my house is quiet"73. Silence takes our hand and walks with us toward the Christic experience.

As we have seen, annotation 20 refers to the benefits of separation. "The more we are alone (1) and by ourselves, the more capable (2) we become of drawing near to and reaching our Creator and Lord, and the more we reach (3) him, the more we make ourselves ready to receive graces and gifts from his divine an supreme goodness"74 [Ex 20].

In this silence, God begins to reveal himself as "quiet music" or as "quiet communication" 75 . Only there can we hear the motion, revealing principle of his presence and will. "The words of wisdom are heard in silence" 76 .

\section{The pilgrimage of the words towards silence}

\section{Words for understanding}

In the Christian religious experience, words make their own pilgrimage, finding their calling to plenitude in humility, in its own process of self-emptying and self-giving.

71 “...en esta primera semana que, aunque se haya traído algunos libros, no es conveniente los lea, antes bien concentre sus pensamientos y afectos en la purificación de su conciencia por medio de lo que se indica para excitar la contrición [...] no se temieran entrevistas con otras personas...” (D20 [57]).

${ }^{72}$ D20 [5.8].

73 “...estando ya mi casa sosegada" (Saint John of the Cross, "Dark Night of the Soul”, stanza 1).

${ }^{74} \mathrm{El}$ apartamiento "por servir y alabar a Dios nuestro Seńor no poco merece delante su divina majestad"; "estando así apartado, no teniendo el entendimiento partido en muchas cosas, mas poniendo el cuidado en solo una, a saber, en servir a su Creador y aprovechar a su propia ánima, usa de sus potencias naturales más libremente para buscar con diligencia lo que tanto desea"; "cuanto más nuestra ánima se halla sola y apartada, se hace más apta para se acercar y llegar a su criador y Señor; y cuanto más así se allega, más se dispone para recibir gracias y dones de la su divina y suma bondad" [Ex 20] (emphasis is mine).

${ }^{75}$ Saint John of the Cross, "Spiritual Canticle", stanza 15 and "Flame of Divine Love" 3, 40.

76 "Las palabras de la sabiduría óyense en silencio" (Eclo 9,17) (Saint John of the Cross, "Flame of Divine Love" 3, 67). 
And the word becomes humble "if and only if" it carries out its mystagogic function of leading the religious subject toward the mystery of God. God's love, and God himself as Love, needed to become accessible to human beings, and this access required words. For being Word, God's accessibility became intelligible, rationality. God opened himself to human beings through words, allowing himself to be known as a first step toward being loved. God became humble for us, becoming flesh and words. Thanks to language we have been able to pronounce one of the deepest question a human been can afford: What is your will, oh God? Talk to me, I am listening.

A response of this kind, uttered from deepest bottom of our soul could only be in words. And that is why God understood it, because he himself became word and uses words to come into our lives. Language of God is always a humble language and uses the common words that we can see in daily newspaper headlines or in the more than twenty thousand millions of whatsapp messages that everyday "are flying" all over the world.

The communicative value of these words coming from God lies in three elements, among them: where they come from, where they are pointing out to and how they manage to transform me as pilgrim words inside me. The petitions of the Exercises are words; they are the lucid, rational form of the desire which underlies their uttering. These words must be pronounced during the process of the Exercises in order to express the retreatant's feeling and desire. In exercises, we become whatever we are able to speak before mystery.

The Spiritual Directors are called to help the retreatant to pronounce the most suitable word related to his/her inner experience in front of the mystery. Only through the light of language I can understand what I am and what God is asking me. Through words, God and I are able to build the relationship Creator-creature.

\section{Words for dying}

We have already said that religious words begotten in Silence are pilgrim words. And all pilgrimages have and end. In the mystic way to the mystery of God, words will be always less in number, but always deeper in meaning. An insistence on holding on to words may slow down or even stop the pilgrimage. Words are aware of when and how they must disappear.

The first words to disappear are those of the First Week, words such as sin, penance, pardon, reconciliation, exam or confession, which have led us to the "Eternal King" [Ex 98]. The same will then happen with those of the Second Week; words as determination, oblation, three types of person, following, Christ's humanity, incarnation, inner knowledge... Once the experience is done and the retreatant has received the 
grace he had been asking for, new steps appear and new words are required. In spiritual life we walk on words searching for the Word. During the First and Second weeks of the Exercises, Creator and creature are involved in a kind of dialogue: language of motions - language of words of the motions, till they reach a moment when a deeper and more strict silence emerges; when the will of God is nearby.

In the heart of the Second Week, the Ignatian method shows his most explicit optimism: if God is asked, he will offer a response. This is "election". The soul can only wait for Silence to possess her: "Therefore, I am going to allure her; I will lead her to the wilderness and speak to her tenderly" (Os 2,14).

The Autograph Directory states: "Upon entering the three or four times of election, he should remain especially secluded, not wishing to see or experience anything that is not from above"77; "he should go into greater than usual seclusion, so that he will neither see nor hear anything that is not heavenly and from God"78. For Fr. Polanco, "he should not see or hear anything which does not come from above, descending from the Father of lights"79; and according to the Directory of Fr. Fabio Fabi: "The time of the election demands the greatest recollection and union with God"80, for it is he who must reveal his will and the exerciser who must listen to his voice.

In a similar way, Gil Gonzalez Davila: "the person entering upon the election should bring along no other concerns or affairs to distract him. For the voice of the Lord is subtle and needs complete attention to be heard"81. Saint John of the Cross integrates solitude, secret and silence: "God is the agent, and that he is secretly speaking to the solitary soul, while the soul keeps silence" ${ }^{2}$.

\footnotetext{
77 “...entrando en los tres o cuatro tiempos de elección, especialmente se encierre, sin querer ver ni sentir cosa que no sea de arriba" (D1 [6]). It is called Autograph because it contains few sentences pronounced by Saint Ignatius about how to give some points of the Spiritual Exercises.

78 “...recogerse más de lo acostumbrado, de modo que no viese ni sintiese nada que no fuese celeste y divino" (D15 [14]). "When embarking upon the three times for properly making an election, a person should more tan usually recollect himself, as was our Father Ignatius' opinion, so that as far as possible the one making the election neither sees nor feels anything but what is heavenly or divine" (D22.23 [84]). 79 “...y no vea ni oiga nada, en cuanto sea posible, que no provenga de la parte superior, descendiendo del Padre de las luces" (D20 [79]).

80 “...en tiempo de elección se requiere el máximo de recogimiento y unión con Dios” (D25 [19]).

81 “...el que viene a elegir no traiga otro cuidado ni negocio que le divierta; que la voz del Señor es delicada para oírla pide toda atención” (D31 [106]).

82 "...es Dios el agente y el que habla secretamente al alma solitaria, callando ella" (Saint John of the Cross, "Flame of Divine Love” 3, 39).
} 
The linguistic and motional pilgrimage continues to Jesus's solemn Silence in the Third Week: at that point, "The divine nature goes into hiding" ${ }^{83}$ [Ex 196], becoming silence, and the retretant asks to feel pain, loss, tears in silence [Ex 193.203]. Here we must note that in this two petitions there are no questions nor words as in previous petitions of the first or second week; only feeling: sorrow, regret, confusion, tears and interior suffering. Words are reaching their final destination.

Experience leads the retretant towards the Silence of the Lord's Passion: “... and he did not reply to anything at all" [Ex 294]. So it is in Vita Christi, following Isaiah 53,7: "he was led like a lamb to the slaughter, and as a sheep before its shearers is silent". And the Carthusian monk continues, "truth must not manifest itself in every time and place; most of the times silence is divine" ${ }^{84}$. Jesus, as depicted by Ignatius in the hours of Passion, is a silent and divine Jesus [Ex 292-296].

The Fourth Week is not for returning to words, but for remaining in the glorified Silence that is pronounced through consolation: "To observe how Christ our Lord fulfills the office of consoler" [Ex 224]. The enumeration of spiritual phenomena that appears in the third definition of consolation given by Ignatius closes with an allusion to silence: "leaving the soul quiet and at peace in her Creator and Lord" [Ex 316.3 $]^{85}$.

So, the pilgrimage toward mystery is a progressive and spontaneous kenotic process of language; or, the vocation of language in the religious process, even in their symbolic dimension (night, light, water, darkness), is to die gradually and give way to a new communicative creature called Silence where all creatures show their true identity.

\section{Silence, consolation and love}

Consolation is the experience of God's silence. Twelve years before the publication of the Exercises, in the letters to Sor Teresa de Rejadell (Venice, 1536), Ignatius showed familiarity with that image of the good angel who communicates from God's own Silence: "it often happens that our Lord moves and drives our soul to one action or

83 “...divinidad se esconde" [Ex 196].

${ }^{84}$ Vita Christi IV, [35]. The Carthusian introduces some Authorities as Saint Anselmo: “...the silence of the Innocent" or Saint John Crisostomo: "He suffers everything in Silence". See: Ludolfo de Saxonia, La vida de Cristo II, Ch. 62 [1], 496-497.

${ }^{85}$ The Spanish text uses the verbs that the English translation avoids: "quietándola y pacificándola en su Criador y Señor" [Ex 316.3]; could we say in English “quiet-ing her and peace-ing her..." More than "leaving her quiet and at peace"? 
another by opening the soul up, that is, by speaking inside it without the din of words, lifting the soul, wholly to his divine love" ${ }^{\text {"6 }}$. What does speaking without voice entail?

Ignatius is, perhaps, referring to the first definition and experience of consolation that will be elaborated in the third rule of first set, as the fulfillment of what was announced in annotation [15], that Creator and creature communicate immediately and that, in this immediacy, even words are overcome:

I use the word consolation when any interior movement is produced in the soul which leads her to become inflamed with the love of her Creator and Lord, and when as a consequence, there is no creature on the face of the Earth that the person can love in itself, but they love it in the Creator and Lord of all things" $[\text { Ex 316.1 }]^{87}$.

Sainte Therese agrees: "The soul understands that the Divine Teacher is teaching without the noise of words and suspending all potencies which would harm rather than help profit" calls this silent music because, as we have said, it is a tranquil and quiet intelligence, without sound of voices; and in it are thus enjoyed both the sweetness of the music and the quiet of silence" 89 . There is in mystic life an experience that consists in love, love without concept and concept without word.

Where does this experience happen? Fr. Nicolás says: "We all need a place inside ourselves where there is no noise, where the voice of the Spirit of God can speak to us, softly and gently, and direct our discernment". We don't have to go in search of this "place" out of ourselves, nor even ask God for that. This place is already there and already given. It is the untouchable and unreachable, the infinite and eternal dimension

\footnotetext{
${ }^{86}$ De Loyola, "Ignatius to Teresa Rejadell (Venice, June 18, 1536)”, 21. “...acaece que muchas veces el Señor nuestro mueve y fuerza a nuestra ánima a una operación o a otra abriendo nuestra ánima; es a saber, hablando dentro de ella sin ruido alguno de voces, alzando toda a su divino amor y nosotros a su sentido" (San Ignacio de Loyola, Obras completas, 662).

${ }^{87}$ I have already tried to demonstrate how this paragraph of the letter to Teresa Rejadell, the first definition of consolation in the Spiritual Exercises [Ex 316.1] and the paragraphs on consolation without previous cause [Ex 330.336] are the same experience. See: García de Castro, El Dios emergente. Sobre la consolación sin causa, 147-150.

88 "Entiende que sin ruido de palabras obra en su alma su maestro y que no obran las potencias de ella, que ella entienda” (Camino de perfección E [Escorial Ms.] 41.2, V [Valladolid Ms.] 23.2).

${ }^{89}$ Saint John of the Cross, The Complete Works, 89; "Dios se comunica por una "inteligencia sosegada y quieta, sin ruido de voces [...] en la quietud del silencio" (Idem, Spiritual Canticle B, 14 [25]). And before: "... as we enter that darkness in which understanding cannot understand, we get to the point where we lack words and, even more, remain in perfect silence and thinking of nothing" (Pseudo Dionisio Areopagita, "Teología mística”, 376).
} 
of our soul. It is the face of our likeness to God, where only the Holy Spirit dwells. It is the place of our identity as creatures.

Thomas Merton, as maybe, Teresa de Rejadell, was put in this place, the place of our religious Silence. It was March 18, 1958, in Louisville:

Then it was as if I suddenly saw the secret beauty of their hearts, the depths of their hearts where neither sin nor desire nor self-knowledge can reach, the core of their reality, the person that each one is in God's eyes [...]. But this cannot be seen, only believed and "understood" by a peculiar gift. ${ }^{90}$

In this silent mystic place, there is no conceptual or linguistic mediation: only a full encounter in Love that cannot have recourse to words. In the absolute character of Love, words become mute: not because they are ineffective or have failed, but because of their own vocation. All words display their rhetorical speech in order to guide us pedagogically toward Love. And when Love comes to us, owing to God's initiative, religious words withdraw silently.

These words know that their work is done and that they have neither semantic nor symbolic competence to contribute to the experience anymore ${ }^{91}$. At this point, Creator and creature are in a different system of communication; direct communication with God is a meta-linguistic and meta-conceptual experience ${ }^{92}$.

\section{Silence, home of loving action}

According to Fr. Adolfo Nicolás: "That means that our hearts are our monasteries and at the bottom of every activity, every reflection, every decision, there is silence, the kind of silence that one shares only with God" ${ }^{\prime 3}$. To transform a heart into a monastery

\footnotetext{
${ }^{90}$ Merton, Conjectures of a Guilty Bystander. Thomas Merton: Spiritual Master. The Essential Writings, 144-145.

${ }^{91}$ Maybe Ludwig Wittgenstein experienced something similar when writing his Tractatus — his only work published during his lifetime- with the famous "what we cannot speak about we must pass over in silence" (Wittgenstein, Tractatus, 7).

${ }_{92}$ Note here we are using "meta" as opposed to "a": this silence arrives at after going through all the mystagogic way of Incarnation — or mystery made Word, concept.

${ }^{93}$ Padre Adolfo Nicolás, "De statu Societatis Iesu": "Por todo ello, aunque pueda sorprender a algunos, entiendo que uno de los retos principales que afronta la Compañía hoy es el de recuperar el espíritu de silencio. [...] Todos estamos necesitados de un lugar en nuestro interior donde no haya ruidos, donde nos pueda hablar la voz del Espíritu de Dios, con suavidad y discreción, y dirigir nuestro discernimiento. Intuyo en esto una verdad muy honda: necesitamos tener la capacidad de convertirnos nosotros mismos en silencio, en vacío, en un espacio abierto que la Palabra de Dios pueda llenar y el Espíritu de Dios pueda inflamar para bien de otros y de la Iglesia. Hoy, más que nunca, cada jesuita debería ser capaz de vivir como un monje en medio del ruido de la ciudad".
} 
requires the "indifference" toward any other created thing, giving them less and less volume in our hearts ${ }^{94}$.

If word allowed God to access the human way of understanding and interpreting everything, through Love the person is accessed into a more divine code ${ }^{95}$. Ignatius does not use a nuptial code or the symbols of interpersonal love to describe one's relationship with God. The image of the kiss, inspired by the Song of Songs, "let him kiss me with the kisses of his mouth" (Song 1,2$)$ and popular in the Western mystical tradition illustrates this plenitude of meta-conceptual communication.

Then, what is the meaning of love for Ignatius, and how does it connects with Silence and Ignatian action? "Contemplation to attain Love" [Ex 230-237] opens a door for us: "I may be able to love and serve his divine Majesty in everything" [Ex 233]. In order to contemplate "God's love" and "be reached by love" we must contemplate the works God already did for me and is eternally doing ${ }^{96}$ for me: "the benefits received — creation, redemption, and particular gifts" [Ex 234]. And for all creation: giving being, "vegetating, sensing and giving understanding" [Ex 235-236]. Contemplating so as to reach love [Ex 230] exposes the Ignatian mysticism of God's Silence, which is manifested in the density of his works in human being's favor.

This is God's way of loving us through the works we have contemplated in the Exercises: Silent God in ministries of consolation. In the points of the contemplation to attain Love [Ex 230-237], Ignatius does not attribute any verb "of saying" to God. God doesn't say anything but he only "acts in Silence", as the plenitude of Love.

God is putting (in gerund, not in past perfect verb time) love much more in deeds than in words. God shows himself mediately through his creatures, in which he remains immutable, silent and eternal, and it is the silent depth of the human heart, where he lives immediately, which allows us to recognize the divine essence of that

\footnotetext{
${ }_{94}^{4}$ The Hesychasts called this process of taking distance of all created thing to become closer to God (and only to God, as Fr. Nicolás says), amerimnia. Thomas Spidlik introduced this virtue in his chapter on Silence, in La oración según la tradición del Oriente cristiano, 387-389.

95 "....in the activity of the will [...] greater reverence is requiered on our part than were we use the intelellect to understand" [Ex 3].

${ }^{96}$ One of the most important keys to understand the "contemplation to attain Love" is the use of the gerund as a linguistic way to express the incessant, continuous and eternal action of God in his/her creation. Better than "action of God" (as if action were something different from God), and from an Ignatian mystical perspective, I think it is more exact to talk about an "acting God" in the world, as if the action were (in fact, it is) something intrinsic to God, a feature of his/her "personality" that he can not spontaneously leave apart; God is "in action" and to understand God like this brings anthropological and pastoral consequence to understand all ministries of the Jesuits, as "contemplatives in action".
} 
showing. Silence becomes the dramatic setting of the encounter between Creator and creature [again, Ex 15].

If we go back to the metaphor of a nuptial mysticism and claim that works, our actions, everything that we do through what our First Jesuit companions called "ministries", is the way we have of transmitting God's love to the world. In other words: God silently kisses the world through our works, through our ministries.

I believe that here we run into one of the guiding principles of the Ignatian charisma: "Raising our hearts to him, not only in secluded prayer, but also in all other endeavors, offering them to him, showing no less devotion in action than in meditation" ${ }^{\prime 7}$.

As the Father A. Nicolás suggested in the cited "De statu Societatis Iesu" document, converting to Silence aims at keeping the heart inhabited by God's love coming from above which, as Paul wrote to the Romans, "love of God has been poured out into our hearts through the Holy Spirit who has been given to us" (Rm 5,5).

It is the essential dimension of Divinity which does not show itself to the world, that is why it remains Silent and ineffable. Language, on the other hand, is about what shows itself or may be shown. God, as asymtotic limit of religious experience, can only be Silence, a Silence-foundation ${ }^{98}$ which provides religious consistency to everything that is.

How does Ignacio understand works? They are the expression of what is inexpressible; they are what can be shown of the metaphysical and invisible core of the religious experience, that which goes beyond every concept and can only be shown properly through works.

And acting, producing works stemming from the experience of "contemplation to attain Love", is granting a new "linguistic code" to describe the love that is given to me not through words and propositions but through God's works. Action is closer and more self-implicative communication than words. Action communicates more about what is essential to God than word, because Action transforms reality, and this is what spiritual life is about: transformation.

Emptied of one of his most natural means of self-understanding (language), Silence gives birth a mystical way of proceeding rooted in the rhetoric of love's

\footnotetext{
${ }^{97}$ De Ribadeneira, Vita Ignatii de Loyolae, V, 1.7; De Dalmases (ed.), Fontes narrativi de Sancto Ignatio de Loyola IV, 743.

${ }^{98}$ Note we write "Silence-foundation" and not "Silent foundation". From this perspective, God is not a foundation that remains in silence, but a Silence that is the foundation of everything.
} 
humility becoming action. Ignatian ecstasy is our silent action for the glory of God and salvation or our brothers as a response to the silent action God is eternally doing for my/our salvation.

\section{Conclusion}

If there were solemn Silence in the moment of the Nativity of the Lord to express the most solemn action of God "for me and for us"; if the Exercises develop through inner, religious and deictic silence where God can not stop working silently for me and for us..., then, we understand the sacred Silence as the active presence of the Holy Spirit dwelling in me, "making me his temple" (Sp Ex 235) and making me oneness with the most holy process of "laboring and working in all the creatures of the face of the Earth" [236].

It is obvious that we are very far away from the "physical silence" of which the Directories used to speak. This theological Silence is a structure of the soul that from the "monastery of the heart" keeps the ordinary life in permanent contact with the quietness of the Holy Spirit who dwells in everything. It doesn't matter if the person is very or totally dedicated to the "ministries of the word".

The Ignatian anthropology teaches us how to integrate, in a unique religious experience, the most brilliant sermon or speech ever pronounced remaining at the same time rooted in the very Silent reality of God. Even more, only the actions that flow from this Silence will be a real and apostolic word for the "good of others".

In Trinitarian concepts, we could finish by offering the following intuition to be explored, maybe, in the future: the Ignatian mystical experience is a progressive integration in a simple energy nucleus, called "motion", of three infinite human and, then, divine dimensions: love (Father), action (Son) and silence (Holy Spirit).

\section{Bibliography}

À Kempis, Thomas. Imitation of Christ. Edited by W. Creasy. Notre Dame: Ave Maria Press, 1989.

Álvarez, Baltasar. "Escritos acerca de su modo de oración”. In Escritos espirituales, edited by C. Abad and F. Boado, 221. Barcelona: Juan Flors, 1961.

Álvarez, Tomás. "Álvarez, Baltasar, S.J. (1533-1580)”. In Diccionario de Santa Teresa, directed by T. Álvarez, 676-678. Burgos: Monte Carmelo, 2006.

Arrupe, Pedro. La identidad del jesuita en nuestros tiempos. Santander: Sal Terrae, 1981. 
Baldeon-Santiago, Alfonso. "Silencio". In Diccionario de San Juan de la Cruz, edited by Eulogio Pacho, 1313-1320. Burgos: Monte Carmelo, 2000.

Conwell, Joséph. “Deliberaciones 1539”. In Diccionario de espiritualidad ignaciana, by Grupo de Espiritualidad Ignaciana, I, 549-553. Col. Manresa No. 37. BilbaoSantander: Mensajero-Sal Terrae, 2007. . Impelling Spirit. Revisiting a Founding Experience 1539. Chicago: Loyola Press, 1997.

Corominas, J. and J. A. Pascual. Diccionario crítico etimológico castellano hispánico. Vol. V. Madrid: Gredos, 1991.

De Bobadilla, Nicolai Alphonsi. Monumenta Bobadillae. Madrid: Gabrielis López del Horno, [Reimp: Roma, 1970].

De Covarrubias, Sebastián. Tesoro de la lengua castellana o española. Barcelona: Altafulla, 1987.

De Dalmases, Cándido. “Teresa de Jesús”. In Diccionario histórico de la Compañía de Jesús. Vol. IV, 3777-3778. Roma-Madrid: IHSI-U.P. Comillas, 2001.

De Guibert, Joséph. The Jesuits. Their Spiritual Doctrine and Practice. St. Louis (MO): Institute of Jesuits Sources, 1986. [Original: La Spiritualite de la Compagnie de Jesus. Esquisse Historique. Roma: IHSI, 1953. Spanish trans.: La espiritualidad de la Compañia de Jesús. Bosquejo histórico. Santander: Sal Terrae, 1955].

De la Puente, Luis. Vida del padre Baltasar Álvarez. Madrid: Luis Sánchez, 1920.

De Loyola, Ignatius. "Ignatius to Teresa Rejadell (Venice, June 18, 1536)". Letters and Instructions, by Ignatius of Loyola, 21. Saint Louis (MO): Institute of Jesuit Sources, 2006.

De Ribadeneyra, Pedro. Vida de Ignacio de Loyola. Barcelona: Librería de la Vda. e Hijos de J. Subirana, Editores, 1863.

-Vida de Ignacio de Loyola. Edited by Cándido de Dalmases. Romae: Monumenta Histórica Societatis Iesu, 1965.

Dupuy, Michel and Pierre Miquel. "Silence”. In Dictionnaire de Spiritualite. Vol. XIV, 829-859. Paris: Beauchesne, 1990.

Echarte, Ignacio (ed.). Concordancia ignaciana. Col. Manresa No. 16. BilbaoSantander-St. Louis: Mensajero-Sal Terrae-Institute of Jesuit Sources, 1996. 
Endean, Philip. "The Strange Style of Prayer". In The Mercurian Project. Forming Jesuit Culture 1573-1580, edited by T. McCoog, 351-397. Rome-St. Louis IHSI-Institute of Jesuit Sources, 2004.

Evagrius Ponticus. "To Eulogios". In Evagrius of Pontus: The Greek Ascetic Corpus, by Evagrius of Pontus, translated by Robert E. Sinkewicz, 12-59. Oxford: Oxford University Press, 2006.

Falkner, Andreas. "Cartuja”. In Diccionario de espiritualidad ignaciana, by Grupo de Espiritualidad Ignaciana, I, 306-311. Col. Manresa No. 37. Bilbao-Santander: Mensajero-Sal Terrae, 2007.

García de Castro, José. El Dios emergente. Sobre la consolacion sin causa. Col. Manresa No. 26. Bilbao-Santander: Mensajero-Sal Terrae, 2001.

García Mateo, Rogelio. "Imitación de Cristo". In Diccionario de espiritualidad ignaciana, by Grupo de Espiritualidad Ignaciana, I, 994-1001. Col. Manresa No. 37. Bilbao-Santander: Mensajero-Sal Terrae, 2007.

Gonçalves da Câmara, Luis. Memorial. Edited by B. Hernández Montes. Col. Manresa No. 7. Bilbao-Santander: Mensajero-Sal Terrae, 1992.

. Remembering Inigo. Glimpses of the Life of Saint Ignatius of Loyola. The Memoriale of Luis Gonçalves da Câmara. Edited by A. Eaglestone and J. A. Munitiz. London: Gracewing and Inigo Enterprises, 2005.

González Magaña, Emilio. "Apartamiento”. In Diccionario de espiritualidad ignaciana, by Grupo de Espiritualidad Ignaciana, I, 179-181. Col. Manresa No. 37. Bilbao-Santander: Mensajero-Sal Terrae, 2007.

González Quevedo, Luis. “¿Quién tiene miedo al silencio?” Manresa 67 (1995): 327-339.

Iparraguirre, Ignacio. "La oración en la Compañía naciente". AHSI 25 (1956): 455-487.

Jiménez de Cisneros, García. A Book of Spiritual Exercises and the Directory for the Canonical Hours. London: Burns and Oates, 1876. [Repr: Ulan Press, 2012]. . "Exercitatorio de la vida espiritual". In Obras completas, edited by Dom Cipriano Baraut, II, 77-455. Montserrat: Abadia de Montserrat, 1965.

. Obras completas. Vol. I. Introducción e indices. Edited by Dom Cipriano Baraut. Montserrat: Abadía de Montserrat, 1965. 
. Obras completas. Vol. II. Texto. Edited by Dom Cipriano Baraut. Montserrat: Abadía de Montserrat, 1965.

Kaufmann, Cristina. "Silencio". In Diccionario teológico de la vida consagrada, edited by Ángel Aparicio Rodríguez, 1655-1667. Madrid: Claretianas, 1989.

Kolvenbach, Peter-Hans. Selección de escritos (1983-1990). Vol. I. Madrid: Curia del Provincial de España, 1992.

. "Sobre lingüística y teología. Al Seminario Regional de Nápoles (Nápoles, 21 de octubre de 1985)". In Selección de escritos (1983-1990), by P-H. Kolvenbach, I, 587-598. Madrid: Curia del Provincial de España, 1992.

L.D. "De origine domus profesase romanae (1581-1584)". In Fontes Narrativi, edited by Cándido de Dalmases, III, 175-182. Romae: Monumenta Historica Societatis Iesu 1960.

Laird, Martin. Into the Silent Land. London: Darton, Longman and Todd, 2006.

Le Bourgeois, Marie-Amelie. "La rumeur de Dieu dans notre monde". Christus 194 (2002): 200-208.

López Azpitarte, E. "Influencia de Santa Teresa en las obras de D. Álvarez de Paz". Manresa 54 (1982): 25-43.

Ludolfo de Saxonia. La vida de Cristo. 2 vols. Madrid-Roma: U.P. Comillas-IHSI, 2010.

McCulloch, Diarmaid. Silence. A Christian Tradition. London: Penguin Books, 2014.

Masiá, Juan. "Silencio". In Diccionario de espiritualidad ignaciana, by Grupo de Espiritualidad Ignaciana, II, 1651-1654. Col. Manresa No. 38. BilbaoSantander: Mensajero-Sal Terrae, 2007.

Melloni, Javier. (ed.). Compendio breve de los Ejercicios Espirituales. Compuesto por un monje de Montserrat entre 1510-1555. Madrid: Biblioteca de Autores Cristianos, 2006.

. "Las influencias cisnerianas de los Ejercicios". In Las fuentes de los Ejercicios Espirituales, edited by J. Plazaola, 353-378. Bilbao: Mensajero-Universidad de Deusto, 1998.

Merton, Thomas. Conjectures of a Guilty Bystander. Thomas Merton: Spiritual Master. The Essential Writings. Edited by L. S. Cunningham. New York: Paulist Press, 1992.

Missoffe, Anne. “Comme la goutte d'eau”. Christus 49 (2002): 221-228. 
Monumenta Natalis. Epistolae Hieronymi Nadal Societati Iesus ab anno 1546 ad 1577 (et alia sripta). Vol. 1. Madrid: w/e, 1898.

Nadal, Jerónimo. Commentarii de Instituto. Edited by M. Nicolau. (Monumenta Natalis V, MHSI 90). Roma: w/e, 1962.

Nicolás, Adolfo. "De statu Societatis Iesu". Lecture in the $70^{a}$ Congregation of Procurators of the Society of Jesus. Nairobi, July 10, 2012.

O'Malley, John W. The First Jesuits. Harvard (MA): Harvard University Press, 1993. [Spanish trans.: Los primeros jesuitas. Bilbao-Santander: Mensajero-Sal Terrae, 1995].

Osuna, Javier. Amigos en el Señor. Unidos para la dispersión. Col. Manresa No. 18. Bilbao-Santander: Mensajero-Sal Terrae, 1998.

Pseudo Dionisio Areopagita. "Teología mística". In Obras completas, edited by T. Martin, 376. Madrid: Biblioteca de Autores Cristianos, 1990.

Rahner, Karl. Palabras al silencio. Estella (Navarra): Verbo Divino, 1981.

Real Academia Española. Diccionario de autoridades. Vol. III. Madrid: Gredos, 1990.

Ruiz Jurado, M. “Álvarez, Baltasar”. In Diccionario histórico de la Compañía de Jesús, I, 91-93. Roma-Madrid: Instituto Histórico-Universidad Pontificia Comillas, 2001.

Sancti Ignatii de Loyola. Exercitia spiritualia. Edited by J. Calveras. MHSI (100). Roma: 1969.

Saint Ignatius of Loyola. "Reminiscences or Autobiography". In Personal Writings, edited by Joséph A. Munitiz and Philip Endean. 1-64. London: Penguin Books, 2004.

. On giving the Spiritual Exercises. The Early Jesuit Manuscript Directories and the Official Directory of 1599. Edited by Martin E Palmer. St. Louis (MO): Institute of Jesuit Sources, 1996.

. Personal Writings. Edited by Joséph A. Munitiz and Philip Endean. London: Penguin Books, 2004.

. The Spiritual Exercises of Saint Ignatius of Loyola. Translated by M. Ivens. Introduction by G. W. Hughes. London: Gracewing, 2004.

Saint John of the Cross. "Flame of Divine Love". In The Complete Works of Saint John of the Cross, edited by E. Allison Peers, III, 16-216. London: Burns Oates and Washbourne, 1947. 
. "Points of Love". In The Complete Works of Saint John of the Cross, edited by E. Allison Peers, III, 250-257. London: Burns Oates and Washbourne, 1947. . "Spiritual Canticle". In The Complete Works of Saint John of the Cross, edited by E. Allison Peers, II, 1-432. London: Burns Oates and Washbourne, 1947.

. The Complete Works of Saint John of the Cross. Edited by E. Allison Peers. London: Burns Oates and Washbourne, 1947.

San Ignacio de Loyola. Ejercicios espirituales. Introducción, texto, notas y vocabulario by Cándido de Dalmases, S.J. Santander: Sal Terrae, 1987.

. Los directorios de Ejercicios 1540-1599. Col. Manresa No. 23. Edited by Miguel Lop Sebastià. Bilbao-Santander: Mensajero-Sal Terrae, 2000.

. Obras completas. Edited by I. Iparraguirre and C. de Dalmases. Madrid: Biblioteca de Autores Cristianos, 1981.

San Juan de la Cruz. "Dichos de luz y amor 181". In Obras completas, edited by José Vicente Rodríguez and Federico Ruiz Salvador, 105. Madrid: Editorial de Espiritualidad, 2009.

- "Noche oscura del alma" 80. In Obras completas, edited by José Vicente Rodríguez and Federico Ruiz Salvador. Madrid: Editorial de Espiritualidad, 2009.

. Obras completas. Edited by José Vicente Rodríguez and Federico Ruiz Salvador. Madrid: Editorial de Espiritualidad, 2009.

Santa Teresa de Jesús. "Carta a Isabel Osorio (8 de abril de 1580)”. In Obras completas, 1003. Madrid: Biblioteca de Autores Cristianos, 1982.

. Obras completas. Madrid: Biblioteca de Autores Cristianos, 1982.

. "Vida". In Obras completas, 28-191. Madrid: Biblioteca de Autores Cristianos, 1982.

Sells, Michael A. Mystical Languages of Unsaying. Chicago: The University of Chicago Press, 1994.

Sesboüé, Bernard. "Quand Dieu se tait. Silence de Dieu, silence de l'homme". Christus 49 (2002): 155-165.

Society of Jesus. The Constitutions of the Society of Jesus. Edited by G. Ganss. Saint Louis (MO): Institute of Jesuit Sources, 1970.

Špidlik, Tomaš. La oración según la tradición del Oriente cristiano. Burgos: Monte Carmelo, 2004. 
Tomlins, David. "The Meaning and Value of Silence in Christian living". Cistercian Studies 17/2 (1982): 172-180.

Von Balthasar, Hans Urs. "Palabra y silencio”. In Ensayos teológicos I. El Verbo se hizo carne, by H.U. Von Balthasar, 167-190. Madrid: Encuentro, 1964.

. "The Word and Silence". Explorations in Theology I: The Word made Flesh, by H.U. Von Balthasar, 127-146. San Francisco: Ignatius Press, 1989.

Wathen, Ambrose, The Meaning of Silence in the Rule of St. Benedict. Washington: Cistercian Publications, 1973.

Wittgenstein, Ludwig. Tractatus lógico-philosophicus. Madrid: Alianza, 2003.

Zas Friz, Rossano. "La tradición mística ignaciana, I. Autores españoles de los siglos XVI y XVII”. Manresa 76 (2004): 391-406. 